\title{
ФОРМУВАННЯ ПРОФЕСІЙНОЇ ГОТОВНОСТІ МАЙБУТНІХ ЛІКАРІВ У КОНТЕКСТІ ВПРОВАДЖЕННЯ СТУДЕНТОЦЕНТРОВАНОГО ПІДХОДУ
}

\author{
Ivano-Frankivsk National Medical University

\section{FORMATION OF PROFESSIONAL READINESS OF FUTURE DOCTORS IN THE CONTEXT OF IMPLEMENTATION OF THE STUDENT-CENTERED APPROACH}

\begin{abstract}
Мета роботи - аналіз теоретико-методичних основ формування професійної готовності майбутніх лікарів у контексті впровадження студентоцентрованого підходу в закладах вищої медичної освіти України. Реформування системи охорони здоров’я в сучасній Україні актуалізують необхідність інноваційних змін у професійній підготовці майбутніх лікарів, від фахової готовності яких безпосередньо залежить успішне функціонування медицини.

Основна частина. Студентоцентроване навчання як основна вимога Європейського простору вищої освіти (ЄПВО) передбачає якісну трансформацію навчального середовища для студентів та інших осіб, які навчаються, з метою досягнення їх автономії та здатності до критичного мислення на основі результатного підходу, що має важливе значення у формуванні професійної готовності майбутніх фахівців.

Завдяки тому, що студентоцентрований підхід передбачає статус студентів як важливих, активних учасників їхнього власного навчання, суттєво зростає значення їх внутрішньої мотивації до вдосконалення особистісних і професійних якостей. Внутрішня мотивація стає базисом для реалізації змісту фахової підготовки майбутніх лікарів із метою корегування їх особистісно-ціннісних, професійно важливих якостей.

Висновки. Студентоцентрований підхід детермінує усвідомлення студентами важливої ролі опанування навчальної програми. Соціальна функція професійної обізнаності виступає основоположним чинником забезпечення ефективності навчально-пізнавальної діяльності майбутніх фахівців у галузі охорони здоров’я.
\end{abstract}

Ключові слова: студентоцентрований підхід; професійна готовність; охорона здоров’я.

The aim of the work - to analyze theoretical and methodological foundations for the formation of professional readiness of future doctors in the context of implementing a student-centered approach in higher medical education institutions of Ukraine. The reform of the health care system in modern Ukraine emphasizes the need for innovative changes in the professional training of future doctors, whose successful completion depends on the successful functioning of medicine.

The main body. Student-centered learning as the main requirement of the European Higher Education Area (EHEA) involves a qualitative transformation of the learning environment for students and other learners in order to achieve their autonomy and critical thinking ability based on a result-oriented approach that is important in shaping the future professional readiness specialists.

Due to the fact that the student-centered approach provides the status of students as important, active participants in their own education, the importance of their internal motivation to improve their personal and professional qualities increases significantly. Internal motivation becomes the basis for the implementation of the contents of the professional training of future doctors with the aim of correcting their personality-value, professional qualities.

Conclusions. Student-centered approach determines students' awareness of the important role of mastering the curriculum. The social function of professional awareness serves as the fundamental factor in ensuring the effectiveness of educational and cognitive activities of future health professionals.

Key words: student-centered approach; professional readiness; health care.

Вступ. Реформування системи охорони здоров'я в сучасній Україні, зумовлені євроінтеграційними прагненнями громадян, актуалізують необхідність інноваційних змін у професійній підготовці майбутніх лікарів, від фахової підготовки яких безпосе-

(C) М. I. Римарчук редньо залежить успішне функціонування медицини XXI століття. Модернізація національної вищої медичної освіти, закономірно, вимагає практичних заходів задля досягнення відповідності стандартів фахової підготовки українських лікарів західноєвропейським критеріям професійної готовності медика. 
Питання організації освіти студентської молоді відображено в Доповіді Міжнародної комісії з освіти ЮНЕСКО для ХХІ століття, в якій особлива увага звертається на необхідність підвищення якості професійної підготовки майбутніх фахівців. У світлі динамічного інформаційно-комунікаційного розвитку людства Комісія орієнтує сучасну спільноту на диверсифікацію освіти та відповідних програм підготовки фахівців, появу нових видів навчання і професійних знань [5].

Мета роботи - аналіз теоретико-методичних основ формування професійної готовності майбутніх лікарів у контексті впровадження студентоцентрованого підходу в закладах вищої медичної освіти України. Реформування системи охорони здоров'я в сучасній Україні актуалізують необхідність інноваційних змін у професійній підготовці майбутніх лікарів, від фахової готовності яких безпосередньо залежить успішне функціонування медицини.

Основна частина. Під впливом сучасних тенденцій функціонування освітнього простору західноєвропейських країн у вищій школі України відбуваються посутні зміни в організації навчального процесу в університетах - із орієнтованого на викладача до студентоцентрованого. Студентоцентроване навчання як основна вимога Європейського простору вищої освіти (ЄПВО) передбачає якісну трансформацію навчального середовища для студентів та інших осіб, які навчаються, з метою досягнення їх автономії та здатності до критичного мислення на основі результатного підходу [1].

У "Національному освітньому глосарії: вища освіта” акцентується, що студентоцентрований підхід (Student-centered approach/ Learner-centered approach) передбачає розроблення освітніх програм, які зосереджуються на результатах навчання, ураховують особливості пріоритетів особи, що навчається, грунтуються на реалістичності запланованого навчального навантаження, яке узгоджується 3 тривалістю освітньої програми. Водночас студенту надаються більші можливості щодо вибору змісту, темпу, способу та місця навчання [7].

Як стверджує український експерт із реформування вищої освіти I. І. Бабин: "Впровадження студентоцентрованого навчання на практиці інколи стикається з труднощами і непорозумінням через різне тлумачення цього підходу в академічних колах. Із студентоцентрованим навчанням пов'язують гнучке навчання (flexible learning), навчання, що базується на досвіді (experiential learning), самокероване навчання (self-directed learning)” [1].
Проблема організації освітньої діяльності в закладах вищої освіти України відображена в нормативно-правових державних актах, зокрема в законах “Про освіту”, “Про вищу освіту”, Державній національній програмі “Освіта” (Україна XXI століття), Національній доктрині розвитку освіти України у XXI столітті, Національній стратегії розвитку освіти в країні на 2012-2021 роки, Концепції розвитку вищої медичної освіти в Україні, Програмі розвитку вищої медичної освіти до 2015 року.

У сучасних психолого-педагогічних дослідженнях активно вивчаються проблеми професійної підготовки фахівців різних галузей, передусім педагогічної. Водночас певні аспекти професійного становлення медиків та формування їх готовності до виконання професійних обов'язків також стали предметом окремих наукових досліджень. Проблема формування ціннісного ставлення до професіоналізму відображена в працях М. Дьоміної; формування професійної спрямованості учнів на медичну професію - Р. В. Іваненко та Ю. Є. Кьюшиної. У наукових працях І. С. Вітенка, О. В. Денисової, Б. І. Ороховського, Б. А. Ясько та ін. професійна готовність розглядається в контексті аналізу особистісно-професійного становлення лікаря [3].

Автори В. М. Галузяк та С. І. Тихолаз у монографії “Розвиток професійної спрямованості студентів вищих медичних навчальних закладів” [3] розкривають сутність і структуру професійної спрямованості майбутніх лікарів та визначають критерії та показники рівнів їі сформованості. Вчені проаналізували педагогічні умови та розробили модель педагогічного супроводу розвитку професійної спрямованості, яка забезпечує ціннісне ставлення до медичної діяльності, а таким чином і формує їх готовність до виконання професійних обов'язків у галузі охорони здоров'я.

Фахівці в галузі організації медичної освіти стверджують, що ступінь наукового обгрунтування проблеми формування професійної готовності студентів - майбутніх лікарів в освітньому середовищі ВНЗ не відповідає рівню актуальності означеної проблеми, її теоретичної і практичної значущості. Недостатньо висвітлені теоретико-методичні основи формування професійної готовності майбутніх лікарів у контексті впровадження студентоцентрованого підходу в закладах вищої медичної освіти України, що й зумовило тему нашого наукового дослідження.

Професійна готовність як особистісна психологічна якість фахівця є необхідною умовою та ре- 
гулятором діяльності людини під час виконання своїх трудових обов'язків. Аналізуючи сутність цього поняття, вчені дають різні його визначення, розглядаючи як: 1) наявність в особистості певних здібностей (Б. Ананьєв, Н. Левітов, С. Рубінштейн); 2) якісну характеристику особистості (К. Платонов); 3) психологічний стан, суттєву ознаку установи (І. Блажава, Д. Узнадзе); 4) психологічну умову досягнення позитивного результату діяльності (І. Ладанов); 5) комплексну інтегральну характеристику особистості, яка визначається переконаннями, морально-вольовими якостями, стилем поведінки, сформованістю знань про професію та професійно необхідними практичними вміннями та навичками (Р. Романенко; В. Сєріков) [8].

У науковому аналізі змісту готовності до професійної діяльності лікаря важливо враховувати результати досліджень доктора психології, одного 3 основоположників новітньої психологічної галузі “Психології професій” - Є. Зеєра. Вчений диференціює два рівні готовності майбутніх фахівців, для першого з яких характерне прагнення особистості оволодіти певною професією, спеціальністю, а для другого - здатність, підготовленість до певного виду професійної діяльності. Вченим також визначений компонентний склад цих рівнів. У структурі першого рівня виокремлюється: 1) мотиваційний компонет, який включає потребу в праці, зацікавленість професією; уявлення про соціальний статус і престижність професії, матеріальна зацікавленість; 2) пізнавальний - розуміння соціальної значущості, суспільної необхідності обраної професії, визначеність методів досягнення мети; 3) емоційний - почуття професійної гідності, гордість за професійну діяльність; 4) вольовий, який передбачає вміння самоорганізації, здатність мобілізувати свої сили для досягнення мети. На другому рівні готовність до професійної діяльності розглядається як безпосередня сформованість особистісних і професійних якостей, необхідних для успішної реалізації фахових завдань [4].

Основоположне значення у визначенні змісту професійної готовності майбутніх лікарів фахівці відводять специфічним умовам праці та вимогам до особистісних якостей і ціннісних пріоритетів медика. 3 огляду на те, що лікувальна справа належить до професій суб’єктно-суб’єктного типу, а діяльність лікаря відбувається в умовах підвищеної соціально-психологічної напруженості, медична професія вимагає високих інтелектуальних і стійких психоемоційних якостей. Умови праці лікарів пов'язані 3 великими емоційними перевантаженнями, систематичними стресовими ситуаціями, зумовленими екстреною необхідністю приймати оперативні рішення без повної інформації, інтенсивністю та великою кількістю міжособистісних контактів. Складність професійних завдань і обов’язків лікаря зумовлюють високий рівень вимог до його професійної готовності. У кваліфікаційній характеристиці лікаря, затвердженій Міністерством охорони здоров’я України, відзначається, що він повинен: “уміти застосовувати сучасні методи профілактики, диференційної діагностики, лікування, реабілітації та диспансеризації хворих в межах своєї спеціальності, надавати їм швидку та невідкладну медичну допомогу; здійснювати нагляд за побічними діями лікарських засобів; планувати роботу та аналізувати їі результати; вирішувати питання тимчасової або постійної непрацездатності пацієнтів; вести лікарську документацію; дотримуватися принципів медичної деонтології; керувати роботою середнього медичного персоналу; брати активну участь у поширенні медичних знань серед населення; постійно вдосконалювати свій професійний рівень” [3].

Рівень розвитку професійних якостей медичного працівника, на думку Л. Супрун, складає основу його психологічної готовності до майбутньої практичної діяльності та визначає особливості процесу становлення його професіоналізму. До професійно важливих якостей лікаря дослідниця відносить: особистісні (мобільність, комунікабельність, терпимість, доброзичливість, відвертість, відповідальність, самостійність, активність), суб’єктні (високий рівень емпатії, прояву підтримки, самоконтролю поведінки тощо) та індивідні (емоційна стійкість, стабільність, урівноваженість нервовопсихічних процесів, контроль емоцій) [9].

У результаті проведеного І. Вітенком дослідження практичної діяльності медичних працівників виявлено проблематичні сторони професійної готовності лікарів, оскільки недоліки в роботі медичного персоналу викликані: а) відсутністю знань із психологічних дисциплін (85,9%); б) негативним ставленням до професійної діяльності або відсутністю інтересу до неї (56,3 \%); в) проявом негативних особистісних якостей особистості лікаря (65,4 \%); г) пасивністю, пов’язаною з відсутністю внутрішньої позитивної мотивації діяльності (44,7 \%); д) недостатнім розумінням сутності впливу психічних станів на виникнення та розвиток соматичних захворювань (51,5 \%) [2]. 
Необхідно зауважити, що рівень сформованості професійної готовності майбутніх лікарів безпосередньо залежить від педагогічних умов їх навчально-пізнавальної діяльності в закладах вищої медичної освіти, тому важливо, щоб організація освітнього процесу узгоджувалась із динамікою особистісного та професійного розвитку кожного студента. В якості педагогічних умов розвитку професійної готовності майбутніх лікарів визначається: особистісно-орієнтований зміст освіти; практичне включення в процес професійної діяльності та спілкування; застосування інтерактивних методів активізації начальної діяльності студентів майбутніх лікарів; використання педагогіки партнерства у взаємодії викладача і студента [6].

Висновки. Таким чином, важливим чинником забезпечення професійної готовності майбутніх лікарів на сучасному етапі реформування системи вищої медичної освіти стає застосування до організації освітнього процесу студентоцентрованого підходу, що суттєво впливає на особистісний розвиток студентів та їх професійну ідентифікацію. Студенти, одержуючи більші можливості щодо вибору змісту, темпу, способу та місця навчання, стають активними учасниками організації освіт-

\section{Список літератури}

1. Бабин I. Зміна парадигми підходу до навчання в університеті - із орієнтованого на викладача до студентоцентрованого як основна вимога ЄПВО / І. Бабин [Електронний ресурс]. - URL : http://lpehea.in.ua/sites/ default/files/documents/2016/05/babyn_i.i._zbirnyk_voivkup_03.2016.pdf.

2. Вітенко І. С. Психологічні основи підготовки медичних кадрів / І. С. Вітенко. - Х. : Основа, 1995. - 158 с.

3. Галузяк В. М. Розвиток професійної спрямованості студентів вищих медичних навчальних закладів : монографія / В. М. Галузяк, С. І. Тихолаз. - Вінниця : ТОВ “Нілан-ЛТД”, 2016. - 228 с.

4. Зеер Э. Компетентносный подход к модернизации профессионального образования / Э. Зеер, Э. Сыманюк // Высшее образование в России. - 2005. - № 4. - С. 23-30.

5. Лещенко О. Політика ЮНЕСКО в освітній сфері / О. Лещенко // Україна-Європа-Світ : зб. наук. праць [Електронний ресурс]. - URL : http://dspace.tnpu.edu.ua/ bitstream/123456789/7821/1/Leshchenko.pdf.

\section{References}

1. Babyn, I. (2016). Zmina paradyhmy pidkhodu do navchannia $v$ universyteti - iz oriientovanoho na vykladacha do studentotsentrovanoho yak osnovna vymoha YEPVO [The change of the paradigm of the approach to university нього процесу. Це суттєво впливає на зростання їх внутрішньої мотивації до вдосконалення особистісних і професійних якостей, що, у свою чергу, стає базисом для реалізації змісту фахової підготовки майбутніх лікарів, формування їх особистісноціннісних, професійно важливих якостей. Важливим якісним показником студентоцентрованого підходу правомірно вважається розширення автономії студентів у виборі навчальних курсів. Завдяки тому, що студентоцентрований підхід передбачає статус студентів як важливих, активних учасників їхнього власного навчання, суттєво зростає значення їх внутрішньої мотивації до вдосконалення особистісних і професійних якостей. Студентоцентрований підхід детермінує усвідомлення студентами важливої ролі опанування навчальної програми, психологічних умінь і здатностей як основного знаряддя майбутньої професійної взаємодії, способу фахового самовираження, розв’язання професійних завдань. Необхідність професійної підготовки до майбутньої трудової діяльності та соціальна функція професійної обізнаності виступають основоположним чинником забезпечення ефективності навчально-пізнавальної діяльності майбутніх фахівців у галузі охорони здоров’я.

6. Любіна Л. А. Гендерні особливості формування професійної компетентності майбутніх лікарів : автореф. дис. на здобуття наук. ступеня канд. психол. наук / Л. А. Любіна ; Ін-т психології ім. Г. С. Костюка НАПН України. - К., 2015. - 18 с.

7. Національний освітній глосарій : вища освіта. - 2-ге вид., переробл. і доповн. / [авт.-уклад.: В. М. Захарченко, С. А. Калашнікова, В. І. Луговий, А. В. Ставицький, Ю. М. Рашкевич, Ж. В. Таланова] ; за ред. В. Г. Кременя. - К. : ТОВ “Видавничий дім “Плеяди”, 2014. - 100 с.

8. Скоробагата О. М. Готовність до діяльності як психолого-педагогічна проблема / О. М. Скоробагата [Електронний ресурс]. - URL : https://www. sportpedagogy.org.ua/html/journal/2008-01/08somppp.pdf.

9. Супрун Л. М. Психологічний аналіз готовності майбутніх медсестер до професійної діяльності : автореф. дис. на здобуття наук. ступеня канд. психол. наук / Л. М. Супрун ; Ін-т психології АПН України. - К., 1994. - 17 c.

education - from a teacher-centered to student-centered as the main requirement of the EHEA]. Retrieved from: http://pehea.in.ua/sites/default/files/documents/2016/05/ babyn_i.i._zbirnyk_voiv-kup_03.2016.pdf [in Ukrainian]. 
2. Vitenko, I.S. (1995). Psykholohichni osnovy pidhotovky medychnykh kadriv [Psychological bases of training of medical personnel]. Kharkiv: Osnova [in Ukrainian].

3. Haluziak, V.M., \& Tykholaz, S.I. (2016). Rozvytok profesiinoi spriamovanosti studentiv vyshchykh medychnykh navchalnykh zakladiv: monohrafiia [Development of professional orientation of students of higher medical educational institutions: monograph]. Vinnytsia: TOV “Nilan-LTD” [in Ukrainian].

4. Zeer, E., \& Symanyuk, E. (2005). Kompetentnosnyy podkhod k modernyzatsii professyonalnogo obrazovaniya [Competent approach to the modernization of vocational education]. Vysshee obrazovanye v Rossii - Higher Education in Russia, 4, 23-30 [in Russian].

5. Leshchenko, O. Polityka YUNESKO v osvitnii sferi. Ukrayina-Yevropa-Svit : zb. nauk. Prats [UNESCO policy in the educational sphere. Ukraine-Europe-World: collection of scientific works]. Retrieved from: http://dspace.tnpu.edu. ua/bitstream/123456789/7821/1/Leshchenko.pdf.

6. Liubina, L.A. (2015). Henderni osoblyvosti formuvannia profesiinoi kompetentnosti maibutnikh likariv [Gender features of the formation of professional competence of fu- ture physicians]. Candidate's thesis. Kyiv: Institute of Psychology by H.S. Kostiuk NAPAU of Ukraine [in Ukrainian].

7. Zakharchenko, V.M., Kalashnikova, S.A., Luhovyi, V.I., Stavytskyi, A.V., Rashkevych, Yu.M., \& Talanova, Zh.V. (2014). Natsionalnyi osvitnii hlosarii: vyshcha osvita (2-e vyd., pererob. i dop.) [National educational glossary: higher education (2nd type, processing. and add)]. Kremen, V.H. (Ed.). Kyiv: TOV "Vydavnychyi dim "Pleiady" [in Ukrainian].

8. Skorobahata, O.M. (2018). Hotovnist do diialnosti yak psykholoho-pedahohichna problema [Readiness for activity as a psychological and pedagogical problem]. Retrieved from: https://www.sportpedagogy.org.ua/html/journal/200801/08somppp.pdf [in Ukrainian].

9. Suprun, L.M. (1994). Psykholohichnyi analiz hotovnosti maibutnikh medsester do profesiinoi diialnosti [Psychological analysis of the readiness of future nurses for professional activity: author's abstract. dis for obtaining sciences]. Candidathe's thesis. Kyiv: Institute of Psychology of the Academy of Pedagogical Sciences of Ukraine [in Ukrainian]. 